\title{
FOOD GRAIN MARKETING IN OSUN STATE, NIGERIA: A STUDY OF LONG-RUN PRICE INTEGRATION
}

\author{
Akintunde, O.K. ${ }^{1}$, Akinremi, T.B. ${ }^{2}$ and Nwauwa, L.O.E. ${ }^{1}$ \\ ${ }^{1}$ Department of Agricultural Economics, University of Ibadan, Nigeria \\ ${ }^{2}$ Department of Statisitics, University of Ibadan, Nigeria.
}

\begin{abstract}
This study examined the trend in food grain prices in urban and rural market of Osun state, Nigeria . Secondary data on rice and maize monthly prices spanning 2006/2008 were sourced from MacroStatistics Department, Osun State Planning Commission. The data were analyzed using Augmented Dicker Fuller $(A D F)$ test and Index of Market Connection. Empirical results revealed that the price series in all the markets accepted the null hypothesis of non-stationarity at their levels at 5\% significance level. The integration test showed that none of the markets examined had prices tied together in the long-run. The Index of market connection (IMC) indicates that the markets exhibit low short run market integration. The study concludes that the agricultural commodity markets in Osun state may be subject to a high degree of marketing inefficiency and recommends a nation-wide policy to improve food marketing efficiency in Nigeria.
\end{abstract}

Keywords: Food grain, marketing, Nigeria, price integration.

\section{INTRODUCTION}

Important food grain in Nigeria whose production is being emphasized to remedy food deficit and importation includes maize, sorghum, millet, rice and pulses (Aihonsu and Akorede, 2002). Prices are a standard and important component of market and food security analysis because they serve as an indicator of both food availability and food access. Prices are a measure of availability because they tend to rise as the supply of food falls in relation to demand (e.g., poor production, constrained imports of food), and they tend to fall when supply expands in relation to demand (e.g., a bumper harvest). Food prices are also a measure of food access because they affect the household's purchasing power: the ability of a household to acquire goods and services based on the amount of money or other forms of wealth they possess.

Prices observed through time are as a result of a complex mixture of changes associated with seasonal, cyclical, trend and irregular factors. The most common regularity observed in agricultural prices is a seasonal pattern of change. Normally, prices of storable commodities are lowest at harvest time, rise as the season progresses, and reach a peak prior to the next harvest (Olukosi and Ositor, 1990). The purpose of selling directly to consumers is to reduce the charges for possession utility. Anytime an intermediary is forced to own and hold inventory, it must be financed. These finance charges for possession utility are included in the purchase price of the product (Downey and Erickson, 1987).

Storage is the holding of goods from the time of production until when they are needed. Seasonality is a marked characteristic of agricultural production. More than $80 \%$ of the agricultural production in Nigeria is done under rain fed condition (Olukosi et al, 2005). Thus products need to be effectively stored overtime to ensure supply during off season because the demand for farm products is relatively constant all year round. Consumers want the same kind of food all the year round and industries must get continuous supply of raw materials. In order to satisfy these needs, commodities must be stored and preserved until when needed, since storage confers on the commodity the utility of time (Olukosi and Isitor, 1990).

Spatial pricing efficiency examines how prices in different markets over space are related, especially through transportation cost. When spatial trade is efficient, food shortages in deficit regions are transmitted to surplus regions via prices (Arndt et al, 1998) and arbitrage triggers flow of food across space. Through efficient spatial arbitrage, the risk of crop failure in some regions is shared over a large market area, and prices are more stable and food shortage may be prevented. An important step toward improving the functioning of markets in this 
Akintunde, O.K et al.,: Continental J. Agricultural Economics 6 (1): 1 - 9, 2012

case is to understand the nature and effects of transaction costs facing input supplies, farmers, food retailers, and/or consumers (Goetz, 1995).

Agricultural prices greatly influence the pace and direction of agricultural development. Prices serve as market signals of the relative scarcity or abundance of a given product; prices also serve as incentives to direct the allocation of economic resources and to a large extent they determine the structure and rate of economic growth. The liberalization of agricultural markets implies accepting potentially substantial variation in prices across time, space and product form. This price variation is necessary if agricultural markets are to perform its marketing functions (Tschirley, 1995). Information on agricultural commodity price in both developed and developing countries like Nigeria is important to both producers and consumers. Prices vary almost throughout the year and understanding the trend of such variations is therefore essential for good planning by the producers, consumers and policy makers. An average household after the price increase spends as high as $75 \%$ of their income on food compared with an average of $65 \%$ before food crisis (Zoellick, 2008).

The volatility in price of agricultural commodities in Nigeria has been attributed to various factors including variances in bargaining power among consumers, cyclical income fluctuations among sellers and consumers, natural shocks such as flood, pests, diseases, and inappropriate response by farmers to price signals (Gilberts, 1999, Udoh et al 2007, Adebusuyi, 2004). Short- run fluctuations in agricultural commodity prices occur between production seasons (Cashin and Pattillo, 2000). During the harvesting period, farmers offer to the market the minimum price for their products. In the offseason, prices become high due to reduced production and seasonal changes (Akpan, 2002). Product price instability among agricultural commodities is a regular phenomenon in markets across Nigeria (Akpan, 2007). Instability in commodity prices among markets could be detrimental to the marketing system and the economy as a whole. It could cause inefficiency in resource allocation among sellers and consumers depending on the source of variability (that is whether it is induced by supply or demand side or both). It could also increase poverty level among low income earners in the society (Polaski, 2008).

Rice and maize are among staple food items whose prices are highly unstable between seasons in Osun State. Consumers pay different amounts for the same product in different markets separated by few kilometers. Price instability of agricultural commodity would be considered a normal phenomenon if it does not significantly differ from one market to another. On the contrary, if products prices are significantly different among markets it may distort resources flow and may also likely negate some objectives of the governments (Akpan and Aya, 2009).

This paper examines the relationship between price levels of food grain in urban and rural markets of Osun state and seeks to determine whether or not they are linked. This study therefore analyzes the trend in price as well as the level of integration between markets for these food grain items in Osun state and determines the causal relationship between and among the series. The study is based on the assumptions that there is no causal relationship between rural and urban prices of food grain and secondly it is assumed that there is causal relationship between rural and urban prices of staple food grain.

\section{METHODOLOGY}

This section presents the methodological framework adopted for the study. The subsequent subsections deal with nature and sources of data, the scope of data collected and analytical procedures.

Sources and Scope of Data.

The data for this study were obtained from secondary sources. The data was from the monthly price series of Osun State Central Pricing System (CPRS) collected by the Macro-Statistics Department, Osun State Planning Commission. The data collected were the monthly retail prices of food grain (Rice and Maize). Monthly retail prices covering between January, 2006, to December, 2008 inclusive were obtained for rural and urban markets across the state.

Analytical Procedure

The study made use of a combination of analytical tools namely trend analysis, co integration and Ravallion-imc model. 
Test for Stationarity

The first step in carrying out a time series analysis is to check for stationarity of the variables (price series in this case. A series is said to be stationary if the means and variances remain constant over time. It is referred as $\mathrm{I}(0)$, denoting integrated of order zero. Non stationary stochastic series have varying mean or time varying variance. The price series in this study were first tested for stationarity. The purpose was to overcome the problems of spurious regression. A stationary series tends to constantly return to its mean value and fluctuations around this mean value have broad amplitudes, hence, the effects of shocks are only transient. Other attributes of stationary and non-stationary data and their implications in econometric modeling are discussed by Adams (1992), Gujarati (1995) and Juselius (2006).

A variable that is non -stationary is said to be integrated of order $d$, written $I(d)$, if it must be differenced $d$ times to be made stationary. In the same way, a variable that has to be differenced once to become stationary is said to be $I(1)$ i.e., integrated of order 1 . The augmented Dickey Fuller (ADF) was adopted to test for stationarity. This involves running a regression of the form:

$\Delta \mathrm{P}_{\mathrm{it}}=\beta_{1}+\beta_{2 \mathrm{t}}+\delta \mathrm{P}_{\mathrm{it}-1}+\alpha_{1} \sum_{\mathrm{t}=1}^{\mathrm{m}} \beta_{1} \Delta \mathrm{P}_{\mathrm{it}-1}+\ell_{\mathrm{it}}$

Where:

$\Delta=$ first difference operator

$\mathrm{P}_{\mathrm{it}}=$ food grain price series being investigated for stationarity

$\mathrm{t}=$ time or trend variable

The null hypothesis that $\delta=0$ implies existence of a unit root in $\mathrm{P}_{\mathrm{it}}$ or that the time series is non-stationary. The critical values which have been tabulated by Dickey and Fuller (1979), Engle and Yoo (1987) and Mackinnon (1990) are always negative and are called ADF statistics rather than t-statistics. If the value of the ADF statistics is less than (i.e more negative than) the critical values, it is concluded that $P_{\text {it }}$ is stationary i.e $P_{\text {it }} \sim \mathrm{I}(0)$.

When a series is found to be non-stationary, it is first-differenced (i.e the series $\Delta P_{i t}=P_{i t}-P_{i t-1}$ is obtained and the ADF test is repeated on the first-differenced series. If the null hypothesis of the ADF test can be rejected for the first-differenced series, it is concluded that $\mathrm{P}_{\mathrm{it}} \sim \mathrm{I}(1)$. The price series for all the markets included in this study were investigated for their order of integration.

Co-integration Test

Two or more variables are said to be co- integrated if each is individually non-stationary (i.e. has one or more unit roots) but there exists a linear combination of the variables that is stationary. Other attributes of cointegration are as shown in Engle and Yoo (1987) and Silvapulle and Jarasuriya (1994). After the stationarity test, the study proceeds by testing for co-integration between market price series that exhibited stationarity of same order.

The maximum likelihood procedure for co- integration propounded by Johansen (1988), Johansen and Juselius $(1990,1992)$ and Juselius (2006) was utilized. This is because the two-step Engle and Granger procedure suffers from the simultaneity problem and the results are sensitive to the choice of dependent variables (Baulch, 1995). Adopting a one-step vector auto-regression method avoids the simultaneity problem and allows hypothesis testing on the co-integration vector, $r$. The maximum likelihood procedure relies on the relationship between the rank of a matrix and its characteristic roots. The Johansen's maximal eigenvalue and trace tests detect the number of co-integrating vectors that exist between two or more time series that are econometrically integrated. The two variable systems were modeled as a vector auto-regression (VAR) as follows:

$\Delta X_{t}=\mu_{t}+\sum_{t=1}^{k} \Gamma_{i} \Delta X_{t-1}+\pi X_{t-k}+\varepsilon_{t}$

Where:

$\mathrm{X}_{\mathrm{t}}$ is a $\mathrm{N} \mathrm{x} 1$ vector containing the series of interest (staple foodstuffs spatial price series) $г$ and $л$ are matrices of parameters 
$\mathrm{K}=$ number of lags and should be adequately large enough to capture the short-run dynamics of the underlying VAR and produce normally distributed white noise residuals.

$\varepsilon_{\mathrm{t}}=$ vector of errors assumed to be white noise.

Test for Causality

When two series are stationary of the same order and co-integrated, one can proceed to investigate for causality. This is because at least, one Granger-causal relationship exists in a group of co-integrated series (Alexander and Wyeth 1994; Chirwa 2001 and Nielson 2006). The causality test is represented by the error correction equation below:

$\Delta \mathrm{P}_{\mathrm{it}}=\beta_{0}+\beta_{1} P_{i(t-1)}+\beta_{2 j(t-1)}+\sum_{\mathrm{k}=1}^{\mathrm{m}} \delta_{k} \Delta P_{i(\mathrm{t}-k)}+\sum_{\mathrm{h}=1}^{\mathrm{m}} \alpha_{h} \Delta P_{j(t-h)}+\ell_{\mathrm{it}}$

Where:

$\mathrm{m}$ and $\mathrm{n}$ are number of lags determined by Akaike Information Criterion.

Rejection of the null hypothesis (by a suitable F-test) that $\alpha_{\mathrm{h}}=0$ for $\mathrm{h}=1,2$. $\mathrm{n}$ and $=0$ indicates that prices in market $\mathrm{j}$ Granger-cause prices in market $\mathrm{i}$. If prices in $\mathrm{i}$ also Granger-cause prices in $\mathrm{j}$, then prices are determined by a simultaneous field-back mechanism (SFM). This is the phenomenon of bi-directional causality. If the Granger-causality runs one way, it is called unidirectional Granger causality and the market which Granger causes the other is tagged the exogenous market.

Index of market connection (IMC)

The index of market concentration was used to measure price relationship between integrated markets. Following Oladapo and Momoh, (2007) approach, the actual rural price is given by the equation bellow.

$P_{t}=\beta_{0}+\beta_{1} P_{t-1}+\beta_{2}\left(R_{t}-R_{t-1}\right)+\beta_{3} R_{t-1}+\varepsilon_{t}$

Where:

$\mathrm{R}_{\mathrm{t}}=$ urban price (in Naira)

$\mathrm{P}_{\mathrm{t}}=$ rural price (in Naira)

$\mathrm{R}_{\mathrm{t}-1}=$ lagged price for urban market (in Naira)

$\mathrm{R}_{\mathrm{t}}-\mathrm{R}_{\mathrm{t}-1}=$ difference between urban price and its lag (in Naira)

$\mathrm{E}_{\mathrm{t}}=$ error term

$\beta_{\mathrm{o}}=$ constant term

$\beta_{1}=$ coefficient of rural lagged price

$\beta_{2}=$ coefficient of $R_{t}-R_{t-1}$

$\beta_{3}=$ coefficient of urban lagged price

From the estimation of equation (4) above, the Index of Market Connection (IMC) is given by:

$I M C=\frac{\beta_{1}}{\beta_{g}}$ where $0 \leq \mathrm{IMC} \leq \infty$

If:

IMC $<1$ implies high short run market integration

IMC $>1$ implies low short run market integration

IMC $=\infty$ implies no market integration

IMC $=1$ high or short run market integration

\section{RESULTS AND DISCUSSIONS}

Price trend analysis

The lowest price of a bowl of rice ever attained in the rural market of Osun state was $180.00 /$ bowl in January, 2006 while the highest price ever attained in rural market was $\$ 360.00 /$ bowl in March, 2008. Also, the lowest 
price obtained in rice's urban market was $170.00 /$ bowl obtained in January, 2006 while the highest price was obtained in March, 2008 and was $\$ 350.00 /$ bowl, as shown by Figure.1.

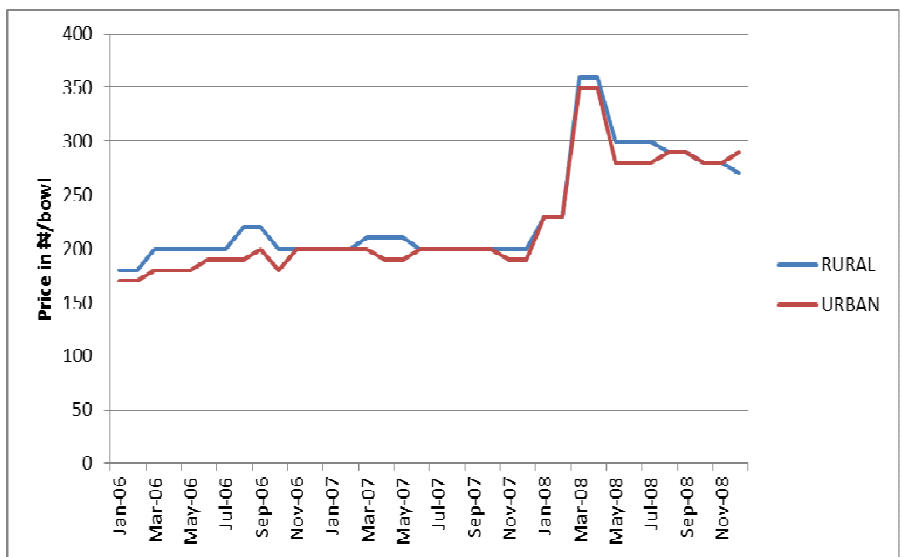

Figure. 1. Trend in rural and urban prices of Rice in Osun State (2006 - 2008).

Similarly, the lowest price of maize that was obtained in the rural market of Osun state was $\$ 82.00 / \mathrm{kg}$ in January, 2006 while the highest price was attained in rural market of $120.00 / \mathrm{kg}$ in March and July, 2008. Also, the lowest price obtained in maize's urban market was $\$ 50.00 /$ bowl obtained in January, 2006 while the highest price was obtained in March, 2008 and was $\$ 120.00$ as shown in figure 2. The reason for the variation in price can be attributed to the economic principle of supply and demand.

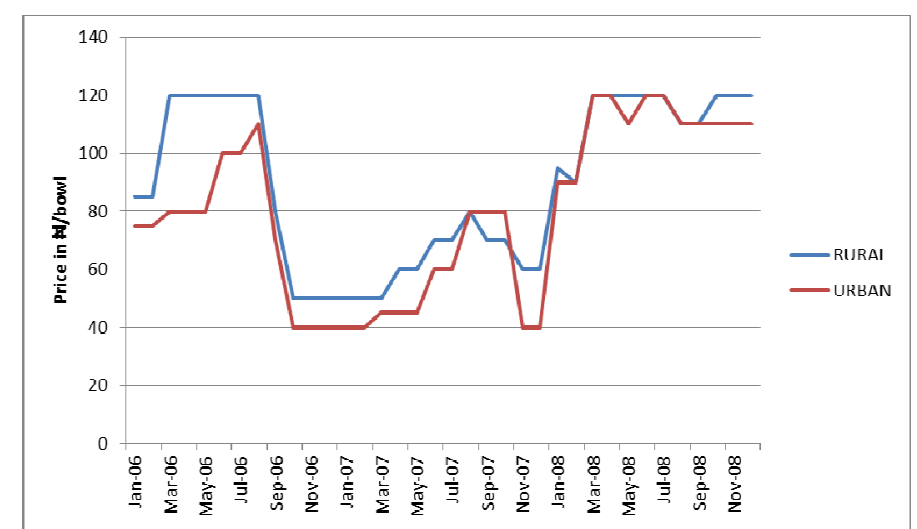

Figure. 2. Trend in rural and urban prices of Maize in Osun State (2006 - 2008).

Stationarity test of food grain price series in Osun State.

The result in Table 1 shows the stationarity test for the food grain using ADF procedure. The results indicate that all the variables are not stationary at their level. The values of the ADF t-statistics were smaller in absolute term than the critical value. This showed that the null hypothesis of non-stationarity could be accepted at the probability of 5 percent level of significance. Therefore, the null hypotheses of non-stationary were accepted for all the variables at their level. When first-differenced, however, the null hypothesis of non-stationarity was rejected in favour of the alternative as the values of the ADF t-statistics were greater in absolute term than the critical value. The findings here corroborate earlier findings that food commodity price series are mostly stationary of order 1 i.e I(1) (Alexander and Wyeth 1994; Ogundare 1999; Franco 1999; Okoh and Egbon 2003; Chirwa 2001; Mafimisebi 2001 and Oladapo 2003). The result is probably explained by the fact that most food price series have trends in them because of inflation and therefore exhibit mean non-stationarity. They need to be first-differenced to become stationary. 
Akintunde, O.K et al.,: Continental J. Agricultural Economics 6 (1): 1 - 9, 2012

Table 1: Results of Unit Root Test of Food Grain Price Series

\begin{tabular}{|c|c|c|c|c|}
\hline \multirow{2}{*}{$\begin{array}{c}\text { Variable } \\
\text { (market price series) }\end{array}$} & \multicolumn{2}{|c|}{ Price level I (0) } & \multicolumn{2}{|c|}{ First difference I (1) } \\
\hline & $\begin{array}{c}\mathrm{ADF} \\
\text { statistics }\end{array}$ & Remarks & $\begin{array}{l}\text { ADF } \\
\text { statistics }\end{array}$ & Remarks \\
\hline Rural Rice Market & -1.5294 & Non-stationary & $-5.7403 * * *$ & Stationary \\
\hline Urban Rice Market & -1.2553 & Non-stationary & $-6.1401 * * *$ & Stationary \\
\hline Rural Maize Market & -1.2266 & Non-stationary & $-4.9200 * * *$ & Stationary \\
\hline Urban Maize Market & -1.631436 & Non-stationary & $-5.1218 * * *$ & Stationary \\
\hline
\end{tabular}

Source: Compiled from result of stationarity test.

Notes: 1. Critical values are -3.6329 and -3.6394 at the 99 percent confidence level for price level and first difference series respectively.

2. *** significant at 1 percent level.

Co-integration Analysis

Co-integration test was carried out on all the variables to determine the existence of long-run relationship between the price variables. Table 2 presents the result of the co-integration test involving the use of Johansen Maximum Likelihood test to determine the number of co-integrating relations. Both the maximal eigenvalue and trace tests are perfectly in agreement of acceptance of null hypothesis of no co-integration at $5 \%$ significance level in all the two market pairs investigated which revealed that there was no long-run equilibrium of market price series. Therefore, there was no perfect transmission of information in all the two m-arket pairs. When there is perfect transmission of price information in a network of markets, producers, marketers and consumers will realize the appropriate gains from trade because correct price signals will be transmitted down the marketing chain thus enabling producers to specialize according to comparative advantage. Markets that are not integrated will convey inaccurate price information that has the tendency to distort production and marketing decisions and contribute to inefficient product movements (Baulch 1997).

Table 2: Johansen Maximum likelihood Tests \& Parameter Estimates for I(1) Market Pairs

\begin{tabular}{|l|c|c|c|c|l|}
\hline $\begin{array}{l}\text { Market } \\
\text { pairs }\end{array}$ & Eigen value & Trace statistics & $\begin{array}{c}\text { Critical } \\
\text { value }(5 \%)\end{array}$ & Probability & $\begin{array}{l}\text { Hypothesized No. } \\
\text { of } \\
\text { Co-integrating } \\
\text { equation }\end{array}$ \\
\hline RUMPR- & 0.23 & 10.31 & 15.49 & 0.26 & None \\
URMPR & 0.03 & 1.23 & 3.84 & 0.27 & At most 1 \\
\hline RUMPM- & 0.32 & 15.20 & 15.49 & 0.06 & None \\
URMPM & 0.07 & 2.31 & 3.84 & 0.13 & At most 1 \\
\hline
\end{tabular}

Source: Compiled from result of Co-integration Test

RUMPR is rural market price of Rice; URMPR is urban market price of Rice while RUMPM is rural market price of Maize and URMPM is urban market price of Maize

The Indices of Market Concentration (IMC).

The result of the indices of market connection (IMC) is presented in Table 4 below. For rice and maize market pairs, the IMC were 1.53 and 3.42 respectively. The IMC for these market pairs were greater than one thus indicating low short run market integration. The results also show that price changes in the rural market do not cause immediate change in the prices in the urban market. Thus, it confirms earlier result of lack of perfect transmission of information in all the two market pairs. 
Akintunde, O.K et al.,: Continental J. Agricultural Economics 6 (1): 1 - 9, 2012

Table 4. Indices of market connection.

\begin{tabular}{|c|c|c|c|c|c|cc|}
\hline $\begin{array}{c}\text { Market } \\
\text { pairs }\end{array}$ & crops & $\mathrm{R}^{2}$ & Adjusted $\mathrm{R}^{2}$ & F statistics & $\mathrm{DW}$ & \multicolumn{2}{|c|}{ IMC classification } \\
\hline $\begin{array}{c}\text { Rural and } \\
\text { urban }\end{array}$ & Rice & 0.96 & 0.96 & 271.09 & 1.65 & $\begin{array}{l}1.53 \text { low short run } \\
\text { market integration }\end{array}$ \\
\hline $\begin{array}{l}\text { Rural and } \\
\text { urban }\end{array}$ & Maize & 0.94 & 0.93 & 149.21 & 1.69 & $\begin{array}{l}3.42 \text { low short run } \\
\text { market integration }\end{array}$ \\
\hline
\end{tabular}

\section{CONCLUSION AND RECOMMENDATIONS}

This study is an evaluation of long-run price integration of food grain marketing in Osun state, Nigeria. The study delineated pice trend and long-run trelationships between market price series. In the analysis of dynamic price relationships in the long-run, the study investigated order of integration of the time series data so that spurious regression estimates could be avoided. The stationary test indicated that the prices were not stationary at level form. However, at first difference prices became stationary thereby leading to the rejection of the null hypothesis of no stationary in the prices of the commodities. The indices of market connection market exhibit low short run market integration which revealed that price changes in the rural market do not cause immediate change in the prices in the urban market. .

The general implication of the findings of this study is that agricultural commodity markets in developing countries may be subject to a high degree of marketing inefficiency owing to regional market segmentation. It also shows that the tendency for price differentials between different areas to reach their equilibrium values quickly is low as is the ability of price differences to converge to their long-run equilibrium levels. Therefore, there is a need for a nation-wide policy to improve food marketing efficiency in Nigeria. The result of this will be an efficiently functioning network of markets that delivers food to consumers at an affordable cost with elimination of exploitative tendencies by any group of market intermediaries. In terms of future research, this result highlights the need to study storage technology, transportation system and access to market information in relation to food grain marketing in the study area.

\section{REFERENCES}

Adams, C.S. (1992). Recent Developments in Econometric Methods: An Application to the Demand for Money in Kenya, AERC Special Paper 15, September.

Adebusuyi, B. S., (2004). Stabilization of commodity market of interest to Africa: Paper presented at the workshop on constraints to growth in sub-Saharan Africa, held in Pretoria South Africa.

Aihonsu, D.Y. and F.A. Akorede, (2002). "Maize Marketing in a Border Community:The Case of Imelo-Alcon Local Government Area of Ogun State Nigeria". A paper presented at the 2002 Annual Conference of the Nigerian Association of Agricultural Economists, held at Ahmadu Bello University,

Akpan, S. B., (2002). Analysis of Gross Margin Efficiency of rice beans and garri in Selected markets in Cross River State. Unpublished undergraduate project work. UNICAL.Zaria, November 5th, 110-120.

Akpan, S. B. (2007). Relative Price Variability and Inflation: A case study of Grain subsector in Nigeria. Unpublished Master Degree Thesis. University of Uyo.

Akpan, S. B. and E.A Aya. (2009). Variances In Consumers Prices Of Selected Food Items Among Markets In Cross River State. Global Journal of Social Sciences Vol 8, No. 2, 2009: 49-52.

Alexander. C. and Wyeth, J. (1994). Co-integration and Market Integration: An Application to the Indonesian Rice Market, Journal of Development Studies, Vol.30, No.4, pp.303-328.

Arndt, C., R. Schiller and F. Tarp, (1998). Maize Markets and Rural Storage in Mozambique, A Spatial and Temporal Analysis http://www.lib.utexas.edu/libs/pcl/map Collection/Africa/Mozambique rel 195.jpg. 
Akintunde, O.K et al.,: Continental J. Agricultural Economics 6 (1): 1 - 9, 2012

Baulch, B. (1997), Testing Food Market Integration Revisited, Journal of Development Studies, Vol.33, No.4, pp.512-534.

Baulch, R.J. (1995). Spatial Price Equilibrium and Food Market Integration, A Ph.D Thesis of the Stanford University.

Cashin, P. and Pattillo, C., (2000). 'Terms of trade shocks in Africa: Are they short-lived or long-lived? IMF Working Paper. Washington, DC: IMF.

Chirwa, E.W. (2001), Liberalization of Food Marketing and Market Integration in Malawi, Report of AERC Sponsored Research.

Dickey, D.A. and Fuller, W.A. (1979). Distribution of Estimators for Autoregressive Time Series with Unit Root, Journal of American Statistical Association, Vol.74, No.366, pp.427-431.

Downey, W.D. and S.P. Erickson, (1987). Agribusiness Management, McGraw Hill Inc., 70.

Engle, R.F. and Yoo, B. (1987). Forecasting and Testing in Co-integrated Systems, Journal of Econometrics, Vol.35, No.2, pp.143-159.

Franco, R. (1999). Testing the Quality-Price Relations in Parmigiano and Padano Cheese Markets, Journal of International Food and Agribusiness Marketing, Vol.10, No.3, pp.19-43.

Gilbert, C., (1999). Commodity risk management for developing countries: paper prepared for the third meeting of the international task force (ITF) held in

Goetz, S.J., (1995). "Markets, Transaction Costs, and Selectivity Models in Economic Development". In Gregory, J.S.(ed.), Prices, Product and People; Analyzing Agricultural Markets in Developing Countries, Lynne Renner publisher, Inc. Baulder, Colorado, 383-402.

Gujarati, D.N. (1995). Basic Econometrics, New York, Mc Graw Hill, 3rd Edition.Geneva 23-24 June 1999.

Johansen, S. (1988). A Statistical Analysis of Co-integration Vectors, Journal of Economic Dynamics and Control, Vol.12, No.2-3, pp.231-54.

Johansen, S. and Juselius, K. (1990). Maximum Likelihood and Inference on Co-integration with Applications to the Demand for Money, Oxford Bulletin of Economics and Statistics, Vol.52, pp.169-210.

Johansen, S. and Juselius, K. (1992). Testing Structural Hypothesis in a Multivariate Co-integration Analysis of the PPP and UIP for the UK, Journal of Econometrics, Vol.53, pp.211-44.

Juselius, K. (2006). The Co-integrated VAR Model: Methodology and Applications, Oxford University Press (manuscript).

Mackinnon, J. (1990). Critical Values for Co-integration Tests, San Diego University of California (San Diego), Department of Economics Discussion Paper 90-4.

Mafimisebi, T.E. (2001). .Spatial Price Equilibrium and Fish Market Integration in Nigeria., Unpublished Ph.D Thesis, University of Ibadan, Nigeria, p.201.

Nielson, M. (2006). Market Integration and Causality in Demand, The Case Study of Farmed Trout in Germany, Paper delivered at the 13th Biennial Conference of International Institute of Fisheries Economics and Trade, Portsmouth, U.K, July 11, Vol.14, p.12.

Ogundare, G.O. (1999). The Determinants of the Traditional Export Crops in Nigeria Using Co-integration Approach, Unpublished M.Sc Thesis, University of Ibadan, p.65. 
Akintunde, O.K et al.,: Continental J. Agricultural Economics 6 (1): 1 - 9, 2012

Okoh, R.N. and Egbon, P.C. (2003). The Integration of Nigeria.s Rural and Urban Foodstuff Markets, A Report of AERC Sponsored Research.

Oladapo, O.O. (2003). Market Integration for Pineapples in Nigeria, An Unpublished Ph.D Thesis, University of Agriculture, Abeokuta, Nigeria.

Oladapo M.O and Momoh S. (2007). Food price Differences and Market integration in Oyo State, Nigeria. International Journal of Agricultural Research. 2(1): 69-74.

Olukosi, J.O. and S.N. Isitor, (1990). An Introduction to Agricultural Marketing and Prices, Principles and Application, Living Books Series G.M Publications, Abuja. 15-20.

Olukosi, J.O., S.U. Isitor and M.O. Ode, (2005). Introduction to Agricultural Marketing and Prices : Principles and Applications, Living Books Series G.M. Publications, Abuja, 15.

Polaski, S., (2008). Rising Food Prices, Poverty and Doha Round. Carnegie endowment for international Peace.

Silvapulle, P. and Jayasuriya, S. (1994). Testing for Philippines Rice Market Integration: A Multiple Cointegration Approach, Journal of Agricultural Economics, Vol.45, No.3, pp.369-380.

Tschirley, D.L., (1995). "Using Micro Computer spreadsheets for spatial and temporal price analysis: An Application to Rice and Maize in Ecuador", In Gregory J.S.(ed.) Prices, Products and People; Analyzing Agricultural Markets in Developing Countries, Lynne Rienner publishers, Inc. Boulder, Colorado., 277-299.

Udoh, E. J., and Sunday B. A., (2007). Estimating Exportable Tree Crop Relative Price Variability and Inflation Movement under different Policy Regimes in Nigeria. European Journal of Social Science. 5(2): 17-26.

Zoellick R. (2008). Food Crisis: How prepared is Nigeria? In Nigeria Sunday THIS DAY Newspaper. April 27, 2008. p. 25.

Received for Publication: 18/10/2011

Accepted for Publication: 12/01/2012

Corresponding author

Akintunde, O.K

Department of Agricultural Economics, University of Ibadan, Nigeria 